\title{
Peer reviewers could do much better
}

Sir - When peers, as in peer review, are not conferencing, site visiting, sitting on study sections or other committees, consulting and even, heaven forbid, vacationing, what are they doing? Word processing, in the form of grant applications, manuscripts, reviews, reports, more reports, letters, faxes and e-mails (the worst). We have in effect become short-story writers. The problem is that good short-story writing is very difficult. It takes time and thought. Yet time is in short supply. Thought too. Do peers have time for proper reviewing, and what is the quality of peers' reviews?

The answer to the first question is precious little. How little time do referees spend on reviewing a manuscript? I've heard of 30 minutes. Although the straightforward can be readily despatched, reviewing is most pertinent when a manuscript falls in the grey zone. Writing but a handful of thoughtful lines easily consumes 30 minutes. If, in addition to being harassed, the referee is nursing some microbial infection, jet-lagged or reeling from a recent lousy review, what can be expected in terms of quality?

Judging by my own experience in the biological sciences, discussions and frank gossip, the general conclusion is like the comment at the bottom of my school reports - could do better. And that's the polite version. Let's forget the positive reviews which can be assumed to cause little inconvenience, although they too can surprise. What about the negatives? Rarely does one get constructive comment. Not infrequently a paper is dismissed in as little as eight lines or even less. And this after 6-8 weeks. Then there is the backhanded review which compliments the authors on a good piece of work only to say that it is not suitable for, say, Nature. Alternatively, when more than a couple of paragraphs are proffered, the referee often betrays either a superficial reading of the text or else a lack of familiarity with the subject. Not infrequently the answer to a criticism can be found in the manuscript. Importantly, reviewing often stigmatizes discussion as speculation. When so few pieces of a jigsaw puzzle are available, how else can connections be made if not by speculation? In other words, how frequently does one come across a stimulating discussion? Note that all of the above examples are accepted by harassed (?) editors.

It is patently clear that reviewing is not a peer's priority. Is not the publication of so many mediocre papers and the surprising proportion that go unreferenced, even by their authors, evidence of this? What can be done about this woeful state of affairs? (1) We need a warts-and-all debate. Can editors be blunt and give us some backroom information? For example, what does an editor do with two vapid eight-line reviews? (2) What about requiring at least one single-spaced page as a criterion for refusal? This runs the double risk of helping the authors and exposing the reviewer.

(3) Most importantly, ways must be found to make reviewing a higher priority. A financial incentive is an obvious idea but would kill off a number of journals; come to think of it, that might not be a bad idea. Or contract reviewing - a free subscription for a number of respectable reviews. The journals could then demand the review in a 2-3 week period which would be welcome to all. Or a Monteverdi CD.

\section{Simon Wain-Hobson}

Unité de Rétrovirologie Moléculaire,

Institut Pasteur,

28 rue du Dr Roux,

75724 Paris cedex 15, France

e-mail:simon@pasteur.fr

\section{Unitary construction}

Sir - The Système International d'Unités (SI) has given us unit names that are uninformative, unintuitive, incomprehensible to outsiders and thus hugely attractive to most scientists. One can only admire the SI's consistent push to replace clarity with opacity, for example in the change from 'disintegrations per second' to 'becquerel'. Although biologists have the Michaelis constant and the centimorgan, we seem well behind physicists in accepting SI-like unit names. Here are some ideas.

pauling. One turn of a protein $\alpha$-helix. ("Do you think 6 paulings is long enough for a transmembrane domain?")

crick. One turn of a DNA helix. ("What happens to transcription when the polymerase site is displaced \pm 0.5 cricks?") watson (or chargaff). One DNA base pair. ("It's a big cDNA, 14 kilowatsons.") huxley. Unit step of a myosin molecule. ("Professor, how many huxleys does myosin take per ATP hydrolysed?”)

koshland. $1 \mathrm{~nm}$ of conformational change. ("Hey, look at that. Leu 197 moved 1.2 koshland when glucose was present.")

nüsslein-volhard. A species' complete set of developmental control genes. ("Not bad, but in Drosophila they've already cloned 0.6 nüsslein-volhard.")

levi-montalcini. Concentration of a growth factor giving $50 \%$ of the maximum response. ("Wow, the levi-montalcini was only 100 pg per ml!")

varmus (with apologies to Bishop,

Weinberg and the rest). 100\%

transformation of a cell population by an oncogene. ("Uh-oh, Src only gave me 0.1 varmus on 3T3 cells.")

Such unit names should provide many benefits to biologists. They will provoke interminable arguments about which scientists should be memorialized, make it harder for students to learn enough to compete with their mentors, and allow older biologists either to congratulate themselves on learning the latest fashions or to lament the decline of civilization (my own preference). But will biologists, like physicists, find these undoubted benefits to be worth the obfuscation produced by such a clumsy and inappropriate system?

Jeffrey B. Miller

Neuromuscular Laboratory,

Massachusetts General Hospital,

149 The Navy Yard, 13th Street,

Charlestown,

Massachusetts 02129, USA

email:miller@helix.mgh.harvard.edu

\section{Not 0 butO}

Sir - In your News story "Novel pathogens beat food safety checks" (Nature 384, 397; 1996), you designate the strain of Escherichia coli 0157:H7. But the first character is wrong. Instead of the numeral 0 (zero), it should be the letter O. Serotypes (serovars) of bacteria are differentiated by the $\mathrm{O}$ (Ohne Hauch) antigen on the cell envelope (outer membrane) and the $\mathrm{H}$ (Hauch) antigen on the flagella.

The source of $\mathrm{O}$ and $\mathrm{H}$ is a paper in the Wiener klinische Wochenschrift $(30,1509-1511 ; 1917)$ by Edmund Weil (1880-1922) and Arthur Felix (1887-1956), "Weitere Untersuchungen über das Wesen der Fleckfieberagglutination" ("Further studies on the nature of typhus agglutination):

"Der kürzeren Ausdrucksweise wegen nennen wir die typische, hauchförmig wachsende Proteuskolonie die H-Form, die ohne Hauch wachsende die O-Form." (Because of the shorter mode of expression we call the typical filmy growing Proteus colony the $\mathrm{H}$-form, the one growing without film the $\mathrm{O}$-form.)

Friedrich Katscher

Mariahilfer Str. 133,

A-1150 Vienna,

Austria 